\title{
A TALE OF CONFUSION: How TRIBUNALS TREAT THE PRESENCE AND ABSENCE OF EVIDENCE OF ACTUAL CONFUSION IN TRADE MARK MATTERS
}

Paul G Scott*

In determining whether two trade marks are likely to cause confusion or deception tribunals consider a number of factors. Two important ones are the presence or absence of evidence of actual confusion. With the presence of such evidence tribunals are more willing to find a likelihood of confusion. With the absence of such evidence tribunals are more willing to find no likelihood of confusion. However, contrary authority exists for both propositions. This article suggests a framework for examining both the presence and absence of actual confusion evidence. It argues that only after closely examining the circumstances of each case should a tribunal regard the presence or absence of actual confusion evidence as probative.

\section{INTRODUCTION}

One of the key issues in both trade mark opposition and infringement proceedings is whether the use of one mark is likely to cause confusion or deception with another mark. ${ }^{1}$ In determining whether a mark is likely to do so tribunals consider a number of factors. ${ }^{2}$ These include whether:

* Solicitor, Baldwin Shelston Waters.

1 Trade Marks Act 1953, ss 8, 9, 16 and 17. The issue also arises in passing off cases. Although this article cites passing off cases it does not discuss the tort. It also relies on United States cases under the Lanham Act.

2 Re Pianotist Co's Application (1906) 23 RPC 774, 777 (EWCA); New Zealand Breweries Ltd v Heineken's Bier Browerij Maatschappij NV [1964] NZLR 115, 139 (CA); Levi Strauss \& Co v Kimbyr Investments Ltd [1994] 1 NZLR 332, 363 (HC). 
(1) the marks look and sound alike; ${ }^{3}$

(2) the marks convey the same or similar idea(s); ${ }^{4}$

(3) the marks appear on the same or similar goods or services; ${ }^{5}$

(4) the price of the goods or services on which the marks appear is expensive or cheap ${ }^{6}$

(5) consumers purchase the goods or services carefully or on impulse; ${ }^{7}$

(6) the goods or services appear in the same or similar retail outlets; ${ }^{8}$

(7) in the case of specialist goods or services what expert evidence there is on the question; ${ }^{9}$

(8) actual incidents of confusion or deception have occurred. ${ }^{10}$

Ultimately the issue, after considering the relevant factors, falls to the tribunal as a matter of fact. ${ }^{11}$ The weight a tribunal gives to the various factors varies from case to case. ${ }^{12}$ This is why tribunals have warned against relying too heavily on previous cases. ${ }^{13}$

3 Re Pianotist, above n 2; Hannaford \& Burton v Polaroid Corporation [1976] 2 NZLR 14, 19 (PC); New Zealand Breweries, above n 2,139-141. If they do confusion and deception is more likely.

4 Jafferjee v Scarlett (1937) 57 CLR 115, 122 (HCA); CPC (UK) Ltd v Keenan (1986) FSR 527, 531 (EWHC); Hannaford v Burton, above n 3, 19; Levi Strauss, above n 2, 363. If they do confusion and deception is more likely than if the marks mean different things or are meaningless.

5 Re Pianotist above n 2, 776; Seahorse [1980] RPC 250 (EWHC); Trade Marks Act 1953, ss 8 and 9. If they do confusion and deception is more likely than if the marks appear on different goods or services.

$6 \quad$ Lancer [1987] RPC 303, 325; VB Distributors v Matsushita (1999) 9 TCLR 349, 360 (HC); Dr Martens v Figgins (1990) 44 IPR 281, 361 (FCA). The more expensive goods are the more carefully consumers purchase and the less likely confusion or deception is.

7 Lancer, above n 6, 325; VB Distributors, above n 6, 325; Dr Martens, above n 6, 361.

8 VB Distributors, above n 6; New Zealand Breweries, above n 2, 139; Re Pianotist Co's, above n 2, 776.

9 Pioneer Hi-Bred Corn Co v Hy-Line Chicks Pty Ltd [1978] 2 NZLR 50, 62 (CA); GE Trade Mark [1973] RPC 297, 321 (HL).

10 See authorities below.

11 New Zealand Breweries, above n 2, 139.

12 VB Distributors, above n 6, 360.

13 New Zealand Breweries, above n 2, 138. 
However, tribunals have sometimes suggested that the presence or lack of evidence of actual confusion is a trump card which determines the issue of likely confusion or deception.

As for presence Lord Diplock noted in GE Trade Mark: "If actual confusion in the past is proved, this is a strong indication that continued confusion is likely..." ${ }^{14}$ Similarly Gault $\mathbf{J}$ in Wineworths $v$ CIVC noted: "Evidence of actual deception is not essential. It is, of course, the best evidence of likely future deception."15

As for absence some tribunals have held the lack of such evidence indicates that no confusion or deception is likely. In Hannaford \& Burton $v$ Polaroid Corporation the Privy Council held the fact there was no evidence of actual confusion over four years trading was "a strong indication that confusion was not and is not in the future likely to occur." 16 Hammond J in VB Distributors Ltd v Matsushita Electric Industrial Co Ltd followed Hannaford \& Burton in holding: "...one of the most accurate tests of likely confusion is whether confusion occurred between the application date and the long delayed hearing date."17

While such statements, with respect, may have been valid in the circumstances of each case, they do not and cannot form an iron rule that actual confusion necessitates a finding of likely confusion and no evidence of confusion means a finding of no likely confusion. Especially the latter situation. Indeed, some tribunals have suggested that the lack of evidence of confusion is meaningless or indeed indicates likely confusion. In Electrolux Ltd $v$ Electrix Ltd Lloyd-Jacob J observed "the more complete the deception, the less likely its detection."18 This indicates that marks may be so alike that they totally deceive consumers. Consequently no evidence of confusion or deception will exist. Millet LJ in Harrods Ltd v Harrodian School Ltd noted: "Absence of such evidence [of confusion] may often be readily explained and is rarely decisive." 19 If one can explain the absence the lack of evidence of confusion will not be probative.

So rather than be definitive, the importance of the presence or lack of such evidence depends on the circumstances of each case. Such evidence or the absence of it may or may

14 GE Trade Mark, above n 9, 321

15 Wineworths Group Ltd v CIVC [1992] 2 NZLR 327, 342 (CA).

16 Hannaford \& Burton, above n 3, 20.

17 VB Distributors, above n 6, 362.

18 Electrolux Ltd v Electrix Ltd (1953) 70 RPC 127, 132 (EWHC).

19 Harrods Ltd v Harrodian School Ltd [1996] RPC 697, 716 (EWCA). 
not be decisive. Whether it is depends on a number of different factors. ${ }^{20}$ This article discusses the factors tribunals should consider in determining whether the presence or absence of actual confusion evidence is probative - let alone definitive. It suggests that tribunals should undertake a careful and structured analysis when dealing with the issue. To that end Part II of this article discusses the meaning of confusion and deception. It examines the type of evidence tribunals have considered constitutes evidence of actual confusion. Tribunals have invariably held that evidence of actual confusion is "notoriously difficult" to obtain. Accordingly Part III examines the reasons why. Part IV considers how tribunals should treat evidence of actual confusion while Part V considers how they should treat the lack of such evidence. Part VI offers some conclusions.

\section{MEANING OF CONFUSION AND DECEPTION AND EVIDENCE OF CONFUSION AND DECEPTION}

The leading New Zealand trade mark case on the meaning of confusion and deception is Pioneer Hi-Bred Corn Company v Hy-Line Chicks Pty Ltd. ${ }^{21}$ Although dealing with a section 16 opposition to registration, its discussion of confusion and deception applies to infringement proceedings. Richardson $\mathrm{J}$ (as he then was) undertook a detailed exegesis of section 16. He discussed confusion and deception holding: ${ }^{22}$

'Deceived' implies the creation of an incorrect belief or mental impression and causing 'confusion' may go no further than perplexing or mixing up the minds of the purchasing public. Where the deception or confusion alleged is as to the source of the goods, deceived is equivalent to being misled in not thinking that the goods, bearing the name of the applicant's mark come from some other source and confused to being caused to wonder whether that might not be the case.

The confusion as to source which Richardson J refers is the incorrect belief that goods or services which bear one mark come from another source whose goods and services bear another mark. ${ }^{23}$ Consumers belief that the goods and services bearing the first mark come from the owner of the other mark. This usually arises when the marks appear on the same or similar products.

20 Michael J Allen "The Role of Actual Confusion Evidence in Federal Trade Mark Infringement Litigation" (1994) 16 Campbell L Rev 19.

21 Pioneer Hi-Bred, above n 9.

22 Pioneer Hi-Bred, above n 9, 62.

23 Allen, above n 20, 28-31. 
This is not the only type of confusion. Confusion as to sponsorship or affiliation can occur. ${ }^{24}$ Here consumers believe that goods or services bearing one mark are associated or affiliated with, or sponsored by, or connected with or a brand extension of goods or services bearing another mark. ${ }^{25}$ The similarity of the marks gives rise to this belief. This type of confusion can arise when the marks appear on different types of goods and services.

The confusion or deception must occur among consumers of the goods and services on which the marks appear. As Richardson J observed in Pioneer Hi-Bred: ${ }^{26}$

It is in relation to commercial dealings with goods that the question of deception or confusion has to be considered and the persons whose states of mind are material are the prospective or potential purchasers of goods to which the applicant may apply his mark and others involved in the purchase transactions.

Such purchasers are presumed to use ordinary care and intelligence. ${ }^{27}$ The standard is of "a reasonably prudent purchaser." 28 This varies with the type of goods. ${ }^{29}$ A purchaser of grand pianos is more prudent than a purchaser of washing powder. Tribunals ignore whether confusion or deception is likely for the "moron in a hurry." ${ }^{30}$

It is not enough that the odd one or two consumers will be confused. Rather a substantial number of persons in the relevant market must be confused or deceived. As Richardson J held in Pioneer Hi-Bred: ${ }^{31}$

The test of likelihood of deception or confusion does not require that all persons in the market are likely to be deceived or confused. But it is not sufficient that someone in the market is likely to be deceived or confused. A balance has to be struck. Terms such as 'a number of people' (Jellinek's Application), 'a substantial number of people' (Smith Hayden \& Co Ltd's Application), 'any considerable section of the public' (New Zealand Breweries Ltd v Heineken's Bier Browerij Maatschappij $N V$ ), and 'any significant number of such purchasers' (Polaroid

24 Allen, above n 20, 32-38.

25 Allen, above n 20, 32.

26 Pioneer Hi-Bred, above n 9, 61.

27 Christiansen (1886) 3 RPC 54 (EWHC); Coombe v Mendit (1913) 30 RPC 709; Goldpack Products Ltd v Citrus Products Ltd [1956] NZLR 661, 664 (EWHC); Rich v Bennetts (1978) 1 NZIPR 188 (SC).

28 Sara Lee Corp v Kayser - Roth Corp (1996) 81 F 3d 455 (4th Cir).

29 VB Distributors, above n 6,360.

30 Morning Star Co-operative Society Ltd v Express Newspapers Ltd (1979) 5 FSR 113, 117 (EWHC).

31 Pioneer Hi-Bred, above n 9, 62. 
Corporation $v$ Hannaford \& Burton Ltd) have been used. As Cooke J put it in his judgment in the case:

That varying terminology in the judgments is a reminder that it is not always necessary that a large number of people should be, or should probably be, of the state of mind in question; rather it is a question of the significance of the numbers in relation to the market for the particular goods. ([1975] 2 NZLR 422, 429).

This does not mean the majority of consumers. ${ }^{32}$ Nor does it matter that a substantial number of consumers would not be confused. ${ }^{33}$

Given these tests on confusion and deception it is instructive to consider what tribunals have treated as evidence of confusion. As Michael J. Allen notes probative evidence of confusion usually, but not exclusively, falls into three categories viz; evidence of:

(1) mistaken purchases and similar evidence;

(2) misdirected communications; and

(3) inquiries as to possible affiliations or relationship. ${ }^{34}$

\section{A Mistaken Purchases and Similar Evidence}

This is the best type of confusion evidence. If a consumer has bought brand $\mathrm{X}$ thinking it is brand $\mathrm{Y}$ there is little doubt that brand has confused or deceived such a consumer. This is especially so if the purchaser gives evidence of his or her confusion. However, there is a caution to accepting such evidence. As the learned authors of Kerly's Law of Trade Marks and Trade Names $\left(12^{\text {th }}\right.$ ed) note: "Even if instances of confusion can be found, it may be rather difficult to satisfy the court; people who make good witnesses tend not be very easy to deceive or confuse." 35 The converse of this is that people who have been befuddled tend not to make good witnesses.

This problem only arises in witness actions. It does not occur in interim injunctions or opposition hearings. Generally in such hearings such evidence is by way of affidavit or statutory declaration. ${ }^{36}$

32 Pioneer Hi-Bred, above n 9, 62.

33 Pioneer Hi-Bred, above n 9, 54.

34 Allen, above n 20, 27.

35 T A Blanco White and Robin Jacob Kerly's Law of Trade Marks and Trade Names (12 ed, Sweet \& Maxwell, 1986) 456.

36 Trade Marks Act 1953, s 68. 
In the United Kingdom and New Zealand, at least, evidence of mistaken purchases or orders does not need to come from the allegedly confused consumers. Traders can give evidence of such purchaser confusion. In HP Bulmer Ltd $v J$ Bollinger SA ${ }^{37}$ Buckley LJ observed: "Not a single publican was called to say that he had experience of customers who had been confused, and the vast majority of sales of Babycham in United Kingdom take place in public houses." 38

Similarly in Wineworths, another case involving alcohol, Gault J noted: "There is a good deal of evidence from members of the trade of purchasers asking for Champagne and being surprised at the price." 39 These comments strongly suggest that United Kingdom and New Zealand courts have no problem with the admissibility of such evidence from traders.

One can contrast this with the position in the United States. There are some Courts who refuse to admit such evidence on the basis it is hearsay. ${ }^{40}$ Other Courts will admit it saying it is not hearsay because it is not offered to prove the truth of the consumer's statement or is admissible due to the state of mind exception to the hearsay problem. ${ }^{41}$ Yet other Courts simply admit such evidence without discussing hearsay. ${ }^{42}$

There are other situations which tribunals have found to be probative evidence of actual confusion. These include situations where the purchaser of one brand having complained about it to the manufacturer of another brand. ${ }^{43}$ Where the purchaser of one

37 HP Bulmer Ltd v J Bollinger SA [1978] RPC 79 (CA).

38 HP Bulmer, above n 37, 106.

39 Wineworths, above n 15, 340 .

40 Transamerica Financial Corp v Trans-American Collections Inc, (1977) 197 USPQ 43 (TTAB); Vitek Systems Inc v Abbott Laboratories (1982) 675 F 2d 190 (8th Cir); Ocean Bio-Chem Inc v Turner Network Television Inc (1990) 741 F Supp 1546 (SD Fela); Versa Products Co v Bifold Co (1995) 50 F3d 189, 194 (3rd Cir); Holidays Inns Inc v Holiday Out in Am (1973) 481 F 2d 445, 448-449 (5th Cir).

41 Programmed Tax Systems Inc v Raytheon Co (1977) 439 F Supp 1728 (SDNY); International Kennel Club, Inc v Mighty Star Inc (1988) 846 F 2d 1079 (7th Cir); Kraft Gen Foods Inc v BC-USA Inc (1993) 840 F Supp 344 (ED Penn).

42 Tools USA \& Equip Co v Champ Frame Straightening Equip (1994) 87 F 3d 654 (4th Cir); For a discussion of US law on the subject see J Thomas McCarthy, Trademarks and Unfair Competition (4 ed, Clark Boardman Callaghan, 2000) 456.

43 Union Carbide Corp v Ever-Ready Inc (1974) 531 F 2d 366, 383-84 (7th Cir); Savin Corp v National Tower Warehouse, Inc (1981) 528 F Supp 636, 640-42 (ND Ga); Midway Mfg Co v Dirkschneider (1981) 543 F Supp 466, 489 (D Neb); Council of Better Business Bureaus Inc v Better Business Bureau Inc (1978) 220 USPQ 282, 297 (SD Fla). 
brand has returned it for repair or a refund to the manufacturer of another brand. ${ }^{44}$ Where a consumer of one brand has written to the manufacturer of another brand seeking information about the first brand. ${ }^{45}$ In a few United States cases disgruntled purchasers of one brand have sued or served legal papers on the manufacturer of another brand. ${ }^{46}$

As these situations show probative evidence of actual confusion does not need to involve an actual mistaken purchases. Courts treat as probative, evidence of a consumer asking for one brand and receiving another. Such evidence can include trap orders. These occur when a party sends a person into a shop to ask for its product. Rather than receive its product the person receives another product bearing the allegedly confusing mark. The person has been sent with that purpose in mind. The House of Lords has termed such trap orders as "distasteful" - but provided they met certain criteria they are admissible evidence. $^{47}$

\section{B Misdirected Communications}

Evidence of misdirected communications involve situations where the owner of products or services bearing one mark receives telephone calls or letters intended for the owner of products or services bearing another mark. The rationale for treating such evidence as probative is that the similarity of the marks has led to confusion and consequently the misdirected communications.

This is most likely so when the marks at issue do not appear in the names of the trade mark owners. If so misdirected communications are likely due to confusion between the marks. However, this is not the usual situation. Rather the more common state of affairs is where the marks are part of the trade mark owners's names. Here tribunals are more equivocal in treating such evidence as probative.

44 Ford Motor Co v Summit Motor Prods Inc (1991) 930 F 2d 277, 297 (3rd Cir); Brunswick Corp v Spinit Reel Co (1987) 832 F 2d 513, 521-22 (10th Cir); Harlequin Enterprises Ltd v Gulf \& Western Corp (1981) 644 F 2d 946; 949 (2nd Cir)

45 International Kennel Club Inc v Mighty Star Inc (1988) 846 F 2d 1090 (7th Cir); The Comic Strip Inc v Fox Television Stations Inc (1989) 10 USPQ 2d 1608, 1612 (SDNY); American Association for the Advancement of Science v Hearst Corp (1980) 498 F Supp 242, 258-59 (DDC)

46 Perini Corp v Perini Construction Inc (1989) 715 F Supp 719, 723 (D Md); Schering Corp v Schering AG (1987) 4 USPQ 2d 1596, 1603-04 (DNJ); Santucci Construction Co v Carlo v Santucci Inc (1978) 200 USPQ 783, 787 (ND I11).

47 Bali Trade Mark [1969] RPC 472, 497-498 (HL); Stillitz v Jones and Higgins Ltd (1942) 60 RPC 15, 17 (EWHC); Smith's Potato Crisps Ltd v Paige's Potato Crisps Ltd (1928) 45 RPC 132 (EWHC); Cellular Clothing Co Ltd $v$ G White \& Co Ltd (1952) 70 RPC 9 (EWHC); Fitchetts Ltd v Loubet \& Co Ltd (1919) 36 RPC 296 (EWHC). 
Some tribunals have treated evidence of misdirected communications as evidence of actual confusion between the marks. ${ }^{48}$ Such cases have not discussed the issue in depth.

Other tribunals, on the other hand, have rejected such evidence. ${ }^{49}$ A key factor for doing so is the reason for such misdirected communication. A party relying on such evidence should establish the reason why the misdirected communication occurred. It may have nothing to do with confusion between the two marks. Rather it may be due to "secretarial carelessness caused by a failure to check business addresses." 50 This will especially be so if the letters has the incorrect address of both trade mark owner. ${ }^{51}$ It may also be a result of "inattention and indifference" on the part of the sender or caller. ${ }^{52} \mathrm{~A}$ consumer generally takes more care when forking out dollars for a purchase than when making a phone call or addressing a letter. Carelessness on the part of the Post Office or telephone directory may have caused the misdirected communication. ${ }^{53}$ Misdirected communications may also be due to one trade mark owners's name not having been in the phone book at all or for a very short time. ${ }^{54}$ In such cases what looks like evidence of actual confusion between the marks may be nothing of the sort.

Thus, unless that party relying on misdirected communication gives evidence as to the reasons for the misdirection it runs the risk of a tribunal dismissing such evidence for any or all of the reasons set out above.

In the case of misdirected letters it should be fairly easy to establish the reason. Most letters have a return address. With telephone calls the situation differs. Unless the caller

48 Airport Rentals Ltd v Airport Car Rentals (Southern) Ltd (1995) 6 TCLR 664 (HC); Trade Mark Application No 291864 Marshall Henry in Class 11 (24 May 2000) unreported Assistant Commissioner Howie; Moreream Products Ltd v Heatherfresh (Foods) Ltd [1972] RPC 799, 802 (EWHC); Buler Trade Mark [1996] RPC 141, 144 (EWCA).

49 Theodorus Couwenberger Son Ltd v Diesel Progress NZ Ltd (1988) 2 NZBLC 102, 976 (HC); Coronet Property Group Ltd v Coronet Equities Ltd (1987) 3 NZCLC 100, 314 (HC); Sterwin AG v Brocades Ltd [1979] RPC 481, 491 (EWHC).

50 United States Blind Stitch Machine Corp v Union Special Machine Co (1968) 287 F Supp 468, 472 (SDNY).

51 Noel Leeming Television Ltd v Noel's Appliance Centre Ltd (1985) 5 IPR 249 (HC).

52 Belleville News-Democrat Inc v St Clair Country Publishers Inc (1960) Ill App 2d 95 (4th Dist); Duluth News-Tribune Mesabi Publishing Co (1996) 84 F 3d 1093, 1098 (8th Cir).

53 Allstate Insurance Co v Allstate Investment Corp (1962) 210 F Supp 25 (WD La); Polaroid Corp v Polaroid Electronics Corp (1961) 287 F 2d 492 (2nd Cir); Holiday Inns Inc v Holiday Out in America (1973) F 2d 445 (5th Cir).

54 Theodorus Couwenberger Son Ltd above n 49, 976; Lang v Retirement Living Publishing Co (1991) 949 F 2d 576, 583 (2nd Cir). 
gives his or her reason for calling the wrong number a court may discount the evidence. In some cases wrong phone calls may support a finding of no likely confusion. The European $v$ The Economist involved two device marks "The European" and "European Voice" on newspapers. ${ }^{55}$ The European sued the defendant for trade mark infringement over its use of "The European Voice". It gave evidence of people phoning one company and asking for the other. On being told the correct name the callers hung up.

Rattee $\mathrm{J}$ noted the plaintiff had not explained the reason for the wrong calls. He held these misdirected phone calls did not constitute evidence of actual confusion. He observed: 56

But the evidence does show that in each case, when the caller was told that he or she was

speaking to The European newspaper, he or she knew that this was not the same as European

Voice.

Thus, unless a party can explain the reason for the misdirected communication, all one can confidently say is that a tribunal may or may not regard such evidence as evidence of actual confusion.

\section{Inquiries as to Relationships}

This type of evidence involves situations where a consumer on seeing a new mark asks the owner of an existing mark if the new mark is related or sponsored by it. They may ask if the owner of existing mark has extended his or her brand or started a new company. The reason this may be probative evidence of confusion is that the marks are so similar that consumers think the owners must be related. Actually asking this indicates consumers wonder about such a relationship.

Tribunals vary widely in how they treat such evidence. Some have viewed it as probative evidence of confusion. ${ }^{57}$ Conversely other tribunals have disregarded it. ${ }^{58}$ Indeed some have gone so far as to say such evidence indicates no confusion. ${ }^{59}$ As the

55 The European $v$ The Economist [1996] FSR 431 (EWHC).

56 The European, above n 55, 440.

57 Country Floors Inc v Gepner (1991) 930 F 2d 1056 (3rd Cir); International Kennel Club, Inc v Mighty Star Inc (1988) 846 F 2d 1079 (7th Cir); Fuddruckers Inc v Doc's BR Others Inc (1987) 826 F 2d 837, 845 (9th Cir); Jellibeans Inc v Skating Clubs Inc 716 F 2d 1833, 844 (11th Cir); Fuji Photo Film Co v Shiohara Shaji Kabushiki Kaisha (1985) 754 F 2d 591, 593 (5th Cir).

58 Elizabeth Taylor Cosmetics v Annick Goutal SARL (1987) 673 F Supp 1238, 1248 (SDNY); Toys "R" Us Inc v Lamps R US (1983) 219 USPQ 340, 346 (TTAB).

59 Miss World (UK) Ltd v Miss America Pageants Inc (1988) 856 F 2d 1445, 1451 (9th Cir); Jordache Enterprises Inc v Hogg Wyld Ltd (1987) F 2d 1482, 1487 (10th Cir); Taj Mahal Enterprises Ltd v Trump (1990) 745 F Supp 240, 250-251 (DNJ). 
First Circuit Court of Appeals stated in Fisher Stoves Inc v All Nighter Stove Works: "[f]ar from revealing such confusion, [the inquiries and other] statements indicate that these customers, at least, had the difference in source clearly in mind." 60

By itself it appears such evidence is weak and tribunals will generally disregard it.

\section{Confusion Evidence Need Not Occur in Trade}

The evidence of confusion need not occur only in the course of a sale and purchase. Levi Strauss Co v Kimbyr Investments established in New Zealand that post - sales confusion is relevant. ${ }^{61}$ Similarly confusion pre-sale in the form of an advertising campaign suffices. ${ }^{62}$

Examples of non-sales confusion tribunals have considered include confusion by member of the media and court reporters mixing up the marks. ${ }^{63}$ Premier Brands UK Ltd $v$ Typhoon Europe Ltd involved an infringement action over the marks TY.PHOO and TYPHOON. ${ }^{64}$ Typhoo is a brand of tea. Its owner sued the owner of Typhoon which appears on utensils. It gave evidence of a purported instance of confusion between Typhoo and Typhoon which appeared on the television show "Only Fools and Horses." Neuberger $J$ held the scene involved a pun and rather than show confusion only established that the marks sounded alike. ${ }^{65}$ His honour did not reject the evidence because it was not in the course of a sale and purchase.

It is possible to give evidence of actual confusion. Evidence of mistaken purchases is the best type of evidence. With the other types of confusion evidence tribunals have not been consistent in accepting it. Some have disregarded it. Indeed some have treated the purported confusion as establishing no confusion. Thus, a party wishing to call such evidence must be careful to be certain that such evidence does show confusion. That is if it can find such evidence.

60 Fisher Stoves Inc v All Nighter Stove Works Inc (1980) 626 F 2d 193, 195 (1 st Cir).

61 Levi Strauss, above n 2.

62 VB Distributors, above n 6; Donsco Inc v Casper Corp (1978) 587 F 2d 602, 603 (3rd Cir); Multi-Local Media Inc v 800 Yellow Book Inc (1993) 813 F Supp 199, 204 (EDNY); Armstrong Cork Co v Armstrong Plastic Covers Co (1977) 434 F Supp 860, 868 (ED Mo).

63 Pro Hardware Inc v Home Centres of America Inc (1984) 607 F Supp 146 (SD Tex); Koppers Co v KruppKoppers Gmbh (1981) 517 F Supp 836, 842 (WD Pa); Schering Corp v Schering AG (1987) 4 USPQ 2d 1596, 1604 (DNJ).

64 Premier Brands UK Ltd v Typhoon Europe Ltd [2000] FSR 767 (EWHC).

65 Premier Brands, above n 64, 781. 


\section{DIFFICULTIES IN OBTAINING EVIDENCE OF CONFUSION}

As mentioned above, tribunals have consistently and persistently commented on how difficult it is to obtain evidence of actual confusion. ${ }^{66}$ This in part justifies a tribunal's decision to find a likelihood of confusion in the absence of such evidence.

However, a number of reasons justify such comments. Consumers usually do not explain their thinking processes when they buy a product. They may well think they are buying a different brand. If they do not enunciate such thoughts - no one will know. ${ }^{67}$

Even if they have bought the "wrong" product they may never discover their error. The deception has been complete. ${ }^{68}$

Some consumers may discover their error and not bother to do anything about it. ${ }^{69}$ This may be because they do not know to whom to complain or they decide its not worth the effort. This is especially likely if the product involved is cheap. ${ }^{70}$ A consumer is unlikely to complain over an incorrect purchase of a bag of sweets or an ice cream.

Furthermore, the consumers who discover their error may be too embarrassed to complain. ${ }^{71}$ Doing so admits that one has been befuddled. A person may be unwilling to swear an affidavit to this effect or subject him or herself to cross-examination on the matter. They may also not want to take the trouble and time to be involved in a hearing.

Another reason can be that the goods on which the marks appear are all high quality. ${ }^{72}$ A consumer may be happy with his or her mistakes purchase. It works well. Thus, he or she will not bother to complain. If the product is durable and high quality a consumer will

66 VB Distributors, above n 6, 361; Wineworths, above n 15, 342; GE Trade Mark, above n 9, 321; Premier Brands, above n 64; Harold F Ritchie Inc v Chesebrough-Ponds Inc (1960) 281 F 2d 755, 761 (2nd Cir); Alex Pirie \& Sons Ltd's Application (1933) 50 RPC 147, 160 (EWHC).

67 Sandra Edelman "Failure to Conduct a Survey in Trademark Infringement Cases: A Critique of the Adverse Inference" [2000] TMR 746, 764.

68 Electrolux, above n 18, 132; Wineworths, above n 15, 342.

69 Brunswick Corp v Spinit Reel Co (1987) 832 F 2d 513 (10th Cir); Beer Nuts v Clover Club Foods Co (1986) 805 F 2d 920 (10th Cir); Maxim's Ltd v Badonsky (1985) 772 F 2d 388, 393 (7th Cir); Libman Co $v$ Vining Industries Inc (1995) 36 USPQ 2d 1751, 1755 (7th Cir); Olay Co $v$ Cococare Products Inc (1983) 218 USPQ 1028, 1040 (SDNY).

70 Brunswick, above n 69; Beer Nuts, above n 69; Maxim's, above n 69; Libman, above n 69; Olay, above n 69.

71 HP Bulmer, above n 37, 153.

72 Premier Brands, above n 64, 781; Bali Trade Mark, above n 47, 498. 
not need to return or fix it. This opportunity for discovering the mistake reduces considerably.

There are other reasons why confusion evidence may be difficult to find. The new product may only have been on the market for a very short time. ${ }^{73}$ It may have only been available in small quantities. ${ }^{74}$ This restricts the opportunity for confusion. The products may have been sold in different geographic markets. ${ }^{75}$ This means there has been no opportunity for confusion.

Thus tribunals are correct in pointing out how difficult confusion evidence is to obtain. When they have it they tend to take it seriously.

\section{TREATMENT OF EVIDENCE OF ACTUAL CONFUSION}

Tribunals have repeatedly said that evidence of actual confusion is probative evidence of likely confusion. Some tribunals have described as "strong proof", 76 "very strong evidence"77, "convincing evidence", ${ }^{78}$ "the best evidence"79 and "patently the best evidence" 80 of such a likelihood.

Others have not gone so far calling such evidence as a "strong indication"81 and "ordinarily decisive" 82 of such a likelihood.

73 GE Trade Mark, above n 9, 321; Goldpack Ltd v Citrus Products Ltd [1956] NZLR 661; Fisons Horticulture Inc v Vigoro Industries Ltd (1994) 30 F 3d 466, 475-76; (3rd Cir); Hanbor v Laned (1988) 858 F 2d 70 (2nd Cir); Effem Foods v Commissioner of Trade Marks (1996) 7 TCLR 245 (HC); ColgatePalmolive Ltd v Pattron [1978] RPC 635, 666 (PC); Kimberley Clark v Fort Sterling [1997] RPC 877 (EWHC).

74 GE Trade Mark, above n 9, 321; Effem Foods, above n 73; Portakabin Ltd v Powerblast Ltd [1990] RPC 471,480 (EWHC).

75 Edelman, above in 67, 764; Evans v Eradicure [1972] RPC 808 (EWHC).

76 Brunswick, above n 69, 521 .

77 AmBrit Inc v Kraft Inc (1986) 812 F 2d 1531, 1534 (11th Cir).

78 Exxon Corp v Texas Motor Exchange Inc (1980) 628 F 2d 500 (5th Cir).

79 Wineworths, above n 15, 342 .

80 Tools USA \& Equipment Co v Champ Frame Straightening Equipment (1996) 87 F 3d 654 (4th Cir): See also Claudius Ash Sons \& Co Ltd v Invicta Manufacturing Co Ltd (1912) 29 RPC 465, 476; Australian Woollen Mills Ltd v F S Walton \& Co Ltd (1937) 58 CLR 641, 658 "Evidence of actual cases of deception, if forthcoming, is of great weight."

81 GE Trade Mark, above n 9, 321.

82 Resorts of Pinehurst Inc v Pinehurst National Corp (1998) 148 F 3d 417 (4th Cir). 
While such evidence is usually invaluable it is not always decisive. Phrases such as "a strong indication of" and "ordinarily decisive" are not synonymous with "always leads to the conclusion that" or "inevitably results in a finding of." Just as no evidence of actual confusion does not prevent a finding of likely confusion so does the presence of actual confusion evidence not prevent a finding of no likely confusion.

A blanket rule that the presence of actual confusion necessitates a finding of likely confusion would be unwise. Each case depends on its own facts. Tribunals must consider these before pronouncing on likely confusion.

Evidence of actual confusion may not be evidence of confusion between the marks. Rather the products may have similar get-ups which are confusingly similar. ${ }^{83}$ Trade mark liability depends on confusion arising out of the marks alone. ${ }^{84}$ Thus, a tribunal must determine that it is the marks which are causing the actual confusion. It must eliminate the possibility of the get-ups being the cause.

One can summarise the rationale for treating actual confusion as probative by the following syllogism. Confusing marks cause confusion. This mark caused confusion. Therefore this mark is confusing. It necessarily follows that if a mark is confusing it is likely to cause confusion.

The trouble with such reasoning is that the major premise is not always true. Nonconfusing marks can cause confusion. This is why tribunals use the standard of the reasonably prudent purchaser of ordinary intelligence in assessing the likelihood of confusion or deception. ${ }^{85}$ There are undoubtedly consumers in most markets who confuse the most different and distinctive of marks. As Judge Easterbrook observed in Reed-Union Corp v Turtle Wax: $:^{86}$

Befuddlement is part of the human condition. No matter how clear the markings, no matter how different the names, no matter how distinctive the bottles, some confusion is inevitable.

Trade mark law does not concern itself with this gullible fringe of consumers. ${ }^{87}$

The size of the gullible fringe or rate of befuddlement will vary with the nature of the goods and services. It is likely to be smaller with expensive or specialist goods than for

83 Electrolux, above n 18, 132; Bali Trade Mark, above n 47, 492.

84 Hack's Application [1948] 58 RPC 91, 103 (EWHC); Pioneer Hi-Bred, above n 9, 61.

85 Authorities cited, above n 27.

86 Reed Union Corp v Turtle Wax Inc (1996) 37 USPQ 2d 1718, 1720 (7th Cir).

87 Trade Mark Application Nos 221295 \& 221296, Mate's Vineyard in Classes 33 \& 42 (11 May 2000) unreported, Assistant Commissioner Frankel, 10. 
ordinary, cheap consumer goods. United States trade mark law has recognised the inevitable confusion that occurs in every market. ${ }^{88}$ When parties prepare market surveys based on a comparison of two marks they attempt to measure the natural rate of confusion. They do so by comparing one of the marks with a completely different mark. The number of consumers who confuse the different marks is the natural rate of confusion. In ReedUnion the court held the evidence showed the natural rate of confusion among consumers of car polish exceeded 20 percent. ${ }^{89}$

This is important as the evidence of actual confusion may be evidence from people who belong to the gullible fringe. They may be "the moron in a hurry". Such evidence is worthless. Most any mark would confuse such consumers.

In a hearing involving live witnesses who are subject to cross-examination it should be fairly easy to determine whether a person is part of the gullible fringe. The situation differs in opposition hearings and interim injunctions. Here the witness appears only on paper. ${ }^{90}$ It may be extremely difficult for a tribunal to determine whether the witness is a reasonably prudent purchaser. What is a tribunal to do? Some take notice of the occupation of the witness. If the witness is well-educated and in a responsible position they give weight to the evidence of that witness. ${ }^{91}$ As a general rule this is unexceptionable. However, it cannot apply in all cases. The reason for taking account of education and employment is that well educated people in responsible positions are unlikely to do foolish or silly things. This proposition is not necessarily correct as former President Clinton's actions with a blabbermouth in the Oval Office indicate. There can be no definitive solution. Tribunals, however, should closely consider the standard of the person giving evidence of actual confusion.

If traders give evidence of customer confusion it is impossible to assess the consumers actually confused. In such cases, tribunals should consider the number of incidents. The number of incidents is relevant as an isolated incident of confusion does not show a likelihood of confusion. ${ }^{92}$ It is not enough to show "...that at some place, at some time, someone made a false identification."93 If a party can only show a small number of

88 Edelman, above n 67.

89 Reed Union, above n 86, 1720.

90 Trade Marks Act (1953), s 68.

91 Cookie Time Ltd v Griffins Food Ltd (11 December 2000) unreported, High Court, Auckland Registry M 1756/SW00, 8; Caveat Lector: the author was counsel for the defendant.

92 Champions Golf Club v Champions Golf Club (1996) 78 F 3d 1111 (6th Cir). McCarthy, above n 42, 23 47.

93 McGraw-Hill Publishing Co v American Aviation Associates Inc (1940) 117 F 2d 293 (DC Cir). 
incidents, a tribunal should generally place little weight on such evidence. The incidents must be more than de minimis. As the Second Circuit Court of Appeals noted: "Isolated incidents of confusion, especially by unidentified individuals ... is insufficient to establish a likelihood of confusion." 94

De minimis evidence of actual confusion does not necessarily establish a likelihood of consumer confusion. The First Circuit Court of Appeals once observed: ${ }^{95}$

Just as one tree does not constitute a forest, an isolated instance of confusion does not prove

probable confusion. To the contrary, the law has long demanded a showing that the allegedly

infringing conduct carries with it a likelihood of confounding an appreciable number of

reasonably prudent purchasers exercising ordinary care.

This is consistent with Pioneer Hi-Bred which holds the mark likely confuse a substantial number of consumers. ${ }^{96}$

Conversely tribunals should put greater weight on evidence which shows a large number of incidents of confusion. There, it is less likely that the confused consumer is a member of the gullible fringe.

However, one cannot rely on numbers alone. The size of markets varies. Five incidents of confusion in a market for specialist goods can mean much more than fifty incidents in markets for goods that are on sale to the general public.

When assessing numbers of incidents tribunals must also take account of how long the products have been competing. ${ }^{97}$ If it is only for a short time there will have been little opportunity for confusion. Accordingly, the number of incidents (if any) will be considerably less than if the products have competed for a long time.

Tribunals also need to take account of the nature and price of the products on which the marks appear. ${ }^{98}$ With low costs and disposable products consumers are unlikely to complain. ${ }^{99}$ Tribunals should place more weight on confusion evidence concerning such products. Such evidence of confusion is likely the tip of the iceberg. Indeed some tribunals have recognised that generally that number of incidents of actual confusion in a

94 Atlantic Richfield Co v Arco Globus International Co (1997) 43 USPQ 2d 1574 (SDNY).

95 International Association of Machinists \& Aero Workers v Winship Green Nursing Center (1996) 103 F 2d 196, 201 (1 st Cir).

96 Pioneer Hi-Bred, above n 9, 62.

97 GE Trade Mark, above n 9, 321.

98 Authorities cited, above n 69

99 Authorities cited, above n 69 
case exceeds the number of reported cases. ${ }^{100}$ This is especially so with low cost goods. ${ }^{101}$ As the Tenth Circuit observed in Brunswick Corp $v$ Spinit Co $^{102}$ evidence of actual confusion when the product is low priced is "more valuable because purchasers are more likely to avoid the brand in the future than complain."103

With such goods tribunals can infer from a small number of incidents of actual confusion that larger numbers of consumers have been confused.

Hammond J criticised this type of reasoning in VB Distributors. ${ }^{104}$ This involved marks for electronic products. The Hearings Officer held the opponent had established one incident of confusion. She said "further in my opinion it is probable that there are more than the six who came forward."105 Hammond J held the incident was not one of confusion. He criticised the Hearings Officer's comment saying "First, as to the numbers, I do not understand the basis for the commissioner's comment - which is not grounded in any evidence and which strikes me as being speculative ..."106

One can interpret Hammond J's comments in two ways. First, such an inference was impermissible in the circumstances of the case. Secondly such inferences are impermissible in all cases. The former may be valid. The latter is not. With low cost, disposable goods any confusion is likely to be only the tip of the iceberg. With such goods tribunals have made this inference. ${ }^{107}$ They should be permitted to do so. Such reasoning accords with authority and logic.

The evidence of confusion, which a party brings, must also be plausible. This includes testimony from traders. Tribunals have rejected confusion evidence as implausible. Reed Union is an example. ${ }^{108}$ This involved the marks NU FINISH and FINISH 2001. They appeared on car polish. The plaintiff gave evidence of a number of incidents of confusion.

100 AmBrit Inc v Kraft Inc (1986) 812 F 2d 1531, 1543 (11th Cir); NAACP v NAACP Legal Defense Fund (1983) 559 F Supp 1337, 1344 (DDC).

101 Authorities cited, above n 69.

102 Brunswick Corp v Spinit Reef Co (1987) 832 F 2d 513 (10th Cir).

103 Brunswick, above n 102, 520.

104 VB Distributors, above n 6.

105 Trade Mark Application Nos 160182 and 160183 Palsonic \& device in Classes 9 and 11 (22 July 1999) unreported, Assistant Commissioner Frankel 12.

106 VB Distributors, above n 6, 361.

107 AmBrit, above n 100; NAACP above n 100; Brunswick, above n 102; See also Polmien Fuel Economiser $v$ National School of Salesmanship (1943) 60 RPC 219 (EWHC).

108 Reed Union, above n 86. 
The trial court rejected it. As Judge Easterbrook observed on appeal the trial court characterised the evidence as a series of "tall tales". An example was: ${ }^{109}$

[One witness related] the story of an elderly gentleman in Massachusetts who approached a Reed Union sales representative at a gas station to compliment him on the shine of his car. The Reed Union representative said, "Why I use NU FINISH" to which the old gentleman responded, "I do too, but I don't get the same shine." The old gentleman then went to the truck of his car where he produced FINISH 2001. This story might be a fine commercial, but it is inherently unbelievable to this Court.

In determining the issue of whether a mark is likely to cause confusion and deception, the decision is ultimately one for the tribunal. This can be despite the evidence of actual confusion a party leads. ${ }^{110}$ As Lord Upjohn noted in Bali Trade Mark: "...the judicial ear [or eye] has the final say, for in the end it is a question of impression and common sense."111

A tribunal can hear much evidence of confusion. Yet it can still decide the marks were not likely to cause confusion or deception.

The presence of actual confusion evidence is only one of the factors a tribunal considers when considering likely confusion. A non-trade mark situation illustrates this well. In the recent United States presidential election a controversy arose over the infamous butterfly ballot in West Palm Beach, Florida. A number of voters alleged the ballot was so confusing they voted for the wrong candidate. The number of confused voters was allegedly in the thousands. Based on television interviews, several of the befuddled voters were fluent and articulate. A tribunal in determining whether the ballot was confusing would have to make up its own mind by looking at the ballot. The presence of confused voters could not determine the issue. Ultimately, the Florida Courts held the ballot was not confusing despite the plethora of confused voters. ${ }^{112}$

Individual tribunals may have differing attitudes to evidence of actual confusion. As the twelfth edition of Kerly observes at: "It may be noted that some judges are persistently harder to convince by instances of deception than others." ${ }^{113}$

Jacobs $\mathrm{J}$, in a passing off, case set out his view of actual confusion evidence and its relationship to the finding of actual confusion. ${ }^{114}$ His Honour noted: ${ }^{115}$

109 Reed Union, above n 86, 1720.

110 New Zealand Breweries, above n 2.

111 Bali Trade Mark above n 47, 497.

112 Miami Herald, 20 December 2000, A1.

113 T A Blanco White and Robin Jacob, above n 35. 
The proper approach of the court to the question was not in dispute. The judge must consider the evidence adduced and use his own common sense and his own opinion as to the likelihood of deception. It is an overall 'jury' assessment involving a combination of all these factors, see GE Trade Mark [1973] RPC 297 at 321. Ultimately the question is one for the court, not for the witness. It follows that if the judge's own opinion is that the case is marginal, one where he cannot be sure whether there is a likelihood of sufficient deception, the case will fail in the absence of enough evidence on the likelihood of deception. But if that opinion of the judge is supplemented by such evidence then it will succeed. And even if one's own opinion is that deception is unlikely though possible, convincing evidence of deception will carry the day. The Jif lemon case ... is a recent example where overwhelming evidence of deception had that effect. It was certainly my experience in practice that my own view as to the likelihood of deception was not always reliable. As I grew more experienced I said more and more 'it depend on the evidence.

Interestingly before he ascended the bench Jacobs $\mathrm{J}$ was one of the authors of the twelfth edition of Kerly. After his elevation he became consulting editor of the thirteenth edition. ${ }^{116}$ The above extract about some judges being more difficult to convince than others does not appear in the thirteenth edition. Perhaps his honour's experience on the bench is the reason.

This discussion of individual tribunals making up their own mind is not a buying into of a legal realist-like view that issue of likely confusion or deception depends entirely on the individual judge's view. A court does not simply make its own mind up and leave it at that. Rather, it weighs various factors before pronouncing. Judicial impression does not exist in a vacuum. As Gault J noted in Allied Liquor Merchants Ltd v Independent Liquor (NZ) Ltd $^{117}$

Judicial impression can be no more reliable than any other informed impression. It must not be capricious, idiosyncratic or intuitive impression but rather impression formed having regard to the long established tests for the assessment of likely reaction to a mark, label or trade description.

This is not to deny that different tribunals will have differing reactions to evidence of actual confusion. Some will treat it more seriously than others.

114 Neutrogena Corp v Golden Ltd [1996] RPC 473 (EWHC).

115 Neutrogena, above n 114, 482.

116 D Kitchen, D Llewelyn, J Mellor, R Meade, T Moody-Stuart Kerly's Law of Trade Marks and Trade Names (13 ed, Sweet \& Maxwell, London, 2000).

117 Allied Liquor Merchants Ltd v Independent Liquor (NZ) Ltd (1989) 3 TCLR 328, 334 (HC). 
Despite the different attitudes of different tribunals to it evidence of actual confusion can be very probative. Tribunals should consider it. They should bear in mind the persons confused, the number of complaints, the size of the market, the nature and cost of the products, and the opportunity for confusion. Doing so will undoubtedly help resolve the ultimate issue of likely confusion. While it is important to do so one must remember the decision ultimately comes down, to the eye and ear of the individual tribunal.

This not only applies to the presence of evidence of actual confusion - but also to the absence of any such evidence.

\section{ABSENCE OF EVIDENCE OF ACTUAL CONFUSION}

The fact that a party adduces no evidence of confusion does not prevent a finding the mark is likely to cause confusion. ${ }^{118}$ Tribunals often have held a likelihood of confusion when there has been no evidence of actual confusion. ${ }^{119}$ Whether the absence of confusion is probative depends on the circumstances of each case. As Millet LJ observed in Harrods: ${ }^{120}$

Absence of such evidence [or actual confusion] may often be readily explained and is rarely

decisive ... Its weight is a matter for the judge.

The phrase "readily explained" is key. There may be a number of valid reasons for the absence of such evidence. It depends on the facts of each case.

Conversely a party may not be able to explain the absence of such evidence. The absence can be probative and definitive. The leading New Zealand case which apparently holds so is Hannaford \& Burton. ${ }^{121}$ There the Privy Council held the fact there was no evidence of actual confusion over four years trading was a "strong indication that confusion was not and is not in the future likely to occur". Examination of that case shows this statement applies only to that case. It does not lay down a general rule.

Hannaford \& Burton involved a rectification action. The two marks were Polaroid and Solaviod. They appeared on sunglasses. The owner of Polaroid applied to remove

118 T A Blanco White and Robin Jacob, above n 35, 456; Goldpack, above n 27; Saville Perfumery Ltd v June Perfect Ltd (1951) RPC 147, 174 (HL); GE Trade Mark, above n 14; Re Christiansen's Trade Mark (1886) 3 RPC 54 (EWCA); Spalding v Gamage (1913) 32 RPC 273 (HL); Neutrogena, above n 114; Electrolux, above n 18; Lever Bros (Port Sunlight) Ltd v Snowwhite Products Ltd (1949) 66 RPC 84 (EWHC); Portakabin Ltd v Powerblast Ltd [1990] RPC 471, 479 (EWHC).

119 Authorities cited, above n 118.

120 Harrods, above n 19, 716; Allied Liquor above n 117, 337 "... the absence of evidence of deception after a particular practice has been going on for a considerable time must be explained".

121 Hannaford \& Burton, above n 3. 
Solaviod. Its reason was at the time of registration Solavoid was likely to cause confusion or deception. The Privy Council, in overruling the Court of Appeal, held the mark was not likely to do so. Its reasons included the fact the marks did not look and sound alike and conveyed different ideas. An important factor was that there was no evidence of actual confusion. This was important in the circumstances. Both brands had enjoyed large sales over a long period (several years). They had competed for a long period. Both brands were sold in over 1200 retail outlets throughout New Zealand. Both brands were sold side by side in these outlets. Thus, in these circumstances the lack of confusion evidence was significant. This lack of evidence, as mentioned above, was not the only reason for the Privy Council's holding. Rather than being definitive it supported the other reasons. One of these was the finding that most consumers chose sunglasses by reference to style and not to make. ${ }^{122}$ In other words the evidence showed consumers were brand indifferent. They did not care about the brand of glasses.

This should have been the end of the matter. If consumers are indifferent to brand there can be no likelihood of confusion between marks. The lack of evidence of confusion in reality supports the finding of brand indifference.

Using Millet LJ's wording the owner of Polaroid was not able to "readily explain" the absence of actual confusion evidence. As with why confusion evidence is difficult to obtain a number of reasons exist for the lack of confusion evidence.

The marks may have competed only for a short time. ${ }^{123}$ A party may have just recently introduced products bearing its mark. This lack of opportunity for confusion to arise can explain the absence of evidence.

Even if the products have been on sale for a long time the marks may have only been available in small quantities. ${ }^{124}$ Again this leads to a lack of opportunity for confusion to arise. As Lord Diplock noted in GE: "...but the absence of evidence of past confusion may be accounted for by the small extent to which the mark has been used."125

The products may have been sold in different geographic markets. ${ }^{126}$ If so there will be little or no opportunity for confusion to arise. Even if the products have been in the same

122 Hannaford \& Burton, above n 3, 18.

123 Authorities cited, above n 73 .

124 Authorities cited, above n 74 .

125 GE Trade Mark, above n 9, 321.

126 Edelman, above n 67; 764; Evans, above n 75. 
geographic market they may have been sold in different retail outlets. ${ }^{127}$ This too can explain the lack of evidence of actual confusion.

The nature and cost of the product can also explain the lack of actual confusion. ${ }^{128} \mathrm{~A}$ mentioned above, consumers are less likely to complain about confusion with low costs and disposable products. ${ }^{129}$ They may not take the effort. Rather than complain they are more likely to avoid the brand in the future. ${ }^{130}$ This can explain the lack of evidence of actual confusion with such products even though they may have been sold side by side for a long time.

The high quality of the products on which the marks appear can also explain the lack of confusion evidence. A consumer may only discover his or her confusion on complaining about a product. ${ }^{131}$ If the products are high quality a consumer will not complain and thus not discover his or her befuddlement. Bali involved trade marks which appeared on women's undergarments. Lord Guest commented: "Even if a customer was confused, it is not likely that if she was satisfied with the fit of a garment she would complain. Complaint would only wise from dissatisfaction."132

In Bali Lord Upjohn held that the circumstances of purchase meant dissatisfaction and consequently confusion evidence would be unlikely. He held: ${ }^{133}$

But these cases were not "over the counter" sales but cases where there were careful fittings, in some cases no doubt not only of BERLEI and BALI brassieres but other makes as well, before a purchase was made. In such circumstances I can see little, if any, room for evidence of deception or confusion to emerge. After the fitting the customer buys the one that at the same time fits her body and her purse most conveniently. If, when she gets home, she finds that it is a BALI and no a BERLEI (or vice versa) even if she cares at all I cannot believe that she would bother to complain. Further, I should be surprised if confusion emerged on a repeat order.

If the products are high quality a consumer is unlikely to be dissatisfied. He or she will consequently not discover his or her confusion. As Neuberger J noted in Premier Brands: ${ }^{134}$

127 Authorities cited, above n 8.

128 Authorities cited, above n 70 .

129 Authorities cited, above n 70 .

130 Authorities cited, above n 70 .

131 Allen, above n 20, 32; McCarthy, above n 43, 17-43.

132 Bali, above n 47, 492.

133 Bali, above n 47, 498.

134 Premier Brands, above n 64, 784. 
...the high quality of TEL's goods results in there having been a few complaints which would enable confusion to be detected.

The same reasoning can explain lack of confusion evidence where a consumer discovers his or her confusion by returning a product to the wrong manufacturer for repair. ${ }^{135}$ If the goods are high quality they will not likely need to be repaired. This too, limits the scope for discovering confusion.

Another explanatory factor for the lack of evidence of confusion can be that the goods on which the marks appear are at the opposite ends of the market. ${ }^{136}$ A trade mark registration applies to all the goods which fall within its specification. ${ }^{137}$ A registration covers all such goods - both high price and quality ones to low price, low quality ones. The test is fair use of goods falling within the specification. ${ }^{138}$ It is fair use for a party to move its mark from high quality custom - made goods to mass produced ones. The actual use of the marks at hearing may have been at opposite ends of the quality and price spectrum. If so there is unlikely to be much (if any) evidence of actual confusion. This use on different quality goods was why Diplock LJ (as he then was) discounted the lack of evidence of confusion at Court of Appeal level in Bali. He observed: ${ }^{139}$

But there is an additional feature in the present appeal which detracts from the Bali Company's evidence of absence of confusion. The goods which they at present sell under the name BALI brassieres are not in direct competition with those of the Berlei Company. The BERLEI brassieres are mass-produced in various standard sizes, sold over the counter upon the customer's stating the size she is accustomed to use and often without any trial fitting, whereas the BALI brassieres are a more expensive tailor-made product not intended for the mass-produced market and seldom sold without a trail fitting. So long as the Bali Company limit themselves to this trading policy, it may well be that it will seldom occur that a customer seeking a cheap mass-produced BERLEI brassiere will be supplied with an expensive individually fitted BALI brassiere without appreciating the error, although the converse, as Mrs. Lamb's evidence suggests, may not be true. To find that a purchase is cheaper than one expected may lull suspicion and dull the spirit of inquiry. But the actual existing user by the Bali Company of their mark is not the relevant test of likelihood confusion. They may decide at any time to venture in to the cheaper mass-produced market in direct competition with the

135 Authorities cited, above n 44.

136 Bali, above n 47; Premier Brands, above n 64; Sterwin AG v Brocades [1979] RPC 481 (EWHC); Da Vinci [1990] RPC 237 (EWHC); HP Bulmer, above n 37, 126.

137 Pioneer Hi-Bred, above n 9, 61; Hack's Application above n 84, 103.

138 Pioneer Hi-Bred, above n 9, 61; Hack's Application, above n 84, 103; Bali, above n 47, 486.

139 Bali Trade Mark [1968] RPC 426, 435-436 (EWCA). 
Berlei Company, and the use of their mark in relation to brassieres of this kind and quality would be a fair and normal use of the mark which they would be entitled to make of it under section 4(1) of the Act.

Similarly in Premier Brands Neuberger J held a factor explaining the lack of confusion was "...TEL tragets the upper end to the market, whereas TY. PHOO tea is targeted at the mass market."140

Confusion must arise out of the marks alone. As Morton J observed in Hack's Application: ${ }^{141}$

...the effect on the public of the use of any particular get-up or mode of presentation of the product is not the question which has to be determined by the Court upon the application. The true test is whether the use of the mark by itself, in any manner which can be regarded as fair use of it, will be calculated to deceive or cause confusion.

This is relevant here as the marks may appear on goods which have completely different get-ups. ${ }^{142}$ This can obstruct the similarity between the marks. Consequently there will be lessor no evidence of a actual confusion. As Lloyd-Jacob J noted in Electrolux: ${ }^{143}$

The absence of instances of confusion may be variously explained, without affecting the question of the similarity of the two names. Even if the court could assume from teh absence of positive evidence that there were no occasions upon which a potential customer for a vacuum cleaner was confused or deceived by reason of the simultaneous offer for sale by the Plaintiffs and Defendants of their branded goods - an assumption which cannot fairly be made, because the more complete the deception, the less likely its detection - it might well be that this flowed from some differentiation in get-up or presentation which for the time being has obscured the brand name similarity. [emphasis added]

Another explanatory factor for lack of confusion can be that one of the marks may have always been used with another word or phrase. ${ }^{144}$ So rather than thinking of the mark alone, consumers think of it in conjunction with the extra material. This may explain the lack of confusion evidence. ${ }^{145}$

140 Premier Brands, above n 64, 784.

141 Hack's Application, above n 137, 103

142 Electrolux, above n 18; Bali above n 47, 497.

143 Electrolux, above n 18, 132.

144 Lancer, above n 6; Mini-Lift Trade Mark [1995] RPC 128 (EW Patent Office).

145 Lancer, above n 6; Mini-Lift, above n 144, 133. 
The type of consumers involved can also explain a lack of evidence of confusion. ${ }^{146}$ They may be of a type who will not complain. For example, HP Bulmer involved marks which appeared on wine. ${ }^{147}$ The marks had competed for a long period. Two Court of Appeal judges used the lack of evidence of confusion as a key reason in finding no likelihood of confusion. Walker LJ in dissent held the type of consumer in question explained the lack of confusion evidence. He noted: ${ }^{148}$

This case is different, however, because of the nature of the consumer group. It is accepted that nobody who knows anything about wine would ever be confused. But the potential Babycham consumer being a young inexperienced female drinker is very unlikely to admit at the time that she was confused and, I would think, very unlikely to confess it in after years even assuming that she remembered. This adds weight to the evidence of Mr. Martin who dealt direct with consumers and goes a considerable way to answer the argument that the evidence as a result of long concurrent user should have been much stronger.

The public after some initial confusion may have become attuned to the differences between the marks. This will mean there is only a short window of opportunity for confusion to occur. Liability in such cases still arises. As Gault J noted in Allied Liquor "No one is entitled to practice deception until the public get used to it". ${ }^{149}$

The standard mark one all-weather explanation is "the more complete the deception the more difficult its detection". ${ }^{150}$ A party should have other explanations besides this. It is really scraping the bottom of the barrel to rely on this alone.

Thus, there can be a myriad of reasons explaining the lack of confusion evidence. Tribunals should consider all of the them before deciding whether the lack of such evidence is probative - let alone decisive.

However, if one product has only enjoyed small sales or been on the market for a short period or operated in different geographic markets then the lack of evidence of confusion evidence is meaningless. If the marks have competed for a long time then tribunals should consider the other possible reasons for lack of confusion evidence. Only if there is no explanation for the lack of confusion evidence should tribunals consider this lack of

146 Authorities cited, above n 69

147 HP Bulmer, above n 37.

148 HP Bulmer, above n 37, 153.

149 Allied Liquor, above n 117, 336.

150 Allied Liquor, above n 117, 337. Gault J termed this expression deriving from Electrolux as "the old adage". 
evidence probative. ${ }^{151}$ Doing so is a structured, methodical way lessens the chance of error.

However, in the end it still is a decision for the individual tribunal. A tribunal can find likely confusion. This may be despite no evidence of actual confusion over a long period and side by side selling. It is ultimately the tribunal's decision. As Lord Upjohn noted in Bali: ${ }^{152}$

But such a conclusion may bend to the evidence if such evidence show quite clearly that though to the judicial ear confusion would be obvious, yet over a long period no case of confusion has occurred; but even in such case the judicial ear has the final say, for in the end it is a question of impression and common sense.

Even if a tribunal undertakes a structured methodolical examination of the lack of confusion evidence differences in result can arise. The 2 to 1 split in the English Court of Appeal in HP Bulmer shows that. Two striking examples are Bali ${ }^{153}$ and the United States case of Libman Co $v$ Vining Industries. ${ }^{154}$ Bali involved the marks Bali and Berlei which appeared on women's undergarment. Berlei applied to remove Bali from the register. One of its grounds was that Bali was likely to cause confusion or deception with Berlei at the time of registration. The Registrar of Trade Marks and Ungoed-Thomas $J$ on appeal agreed. ${ }^{155}$ The Court of Appeal by a two to one majority reversed. ${ }^{156}$ Both majority decisions of Lord Denning MR and Salmon LJ (As he then was) placed considerable emphasis on the fact that Berlei had shown no evidence of actual confusion. (They dismissed evidence of trap orders). ${ }^{157}$ This lack of evidence of actual evidence led to a finding of no likelihood of confusion. Diplock LJ (as he then was) dissented. He held the trap order evidence was probative. He also held the difference in price and quality of the

151 For cases where tribunals have considered the lack of confusion evidence probative see Hannaford \& Burton, above n 3; HP Bulmer, above n 37; 106-107; Harrods above n 19, 710; Laura Ashley v Coloroll Ltd [1987] RPC 1 (EWHC); VB Distributors, above n 6; Kidax Trade Mark [1959] RPC 295, 308 (EWHC); Cowie v Herbert (1897) 14 RPC 436, 448 (SC); Baker v Rawson (1889) 45 ChD 519; Elvis Presley Trade Mark [1997] RPC 473 (EWHC); Holbrook Ltd's Application (1909) 26 RPC 791, 796 (EWHC); Bar's Leaks (NZ) Ltd v Motor Specialties Ltd [1973] RPC 21 (SC); Lancer [1987] RPC 303 (EWCA).

152 Bali, above n 47, 497.

153 Bali, above n 139.

154 Libman Co v Vining Industries Inc (1995) USPQ 2d 1751 (7th Cir).

155 Bali, above n 139, 146-47.

156 Bali, above n 139.

157 Bali, above n 139, 431, 440. 
goods explained the lack of confusion evidence. ${ }^{158}$ A unanimous five bench House of Lords reversed the majority decision of the Court of Appeal. ${ }^{159}$ Essentially it did so for the same reasons as Diplock LJ. It further explained the lack of confusion evidence on the basis that consumers would not complain because of either the circumstances of purchase or that they were not dissatisfied and would not complain of the wrong choice. ${ }^{160}$

Libman involved a registered trade mark on a broom. The mark involved was a colour scheme on the bristles. Libman owned the mark. It sued a rival Vining for trade mark infringement over Vining's allegedly confusing colour scheme on bristles on its brooms. The district court held for Libman. It found the Vining's mark was likely to confuse consumers. There was no evidence of actual confusion. The district court held this did not prevent a finding of likely confusion. The Seventh Circuit Court of Appeals by 2 to 1 reversed the district court. ${ }^{161}$ For the majority Chief Judge Posner (as he then was) held Vining's mark was not likely to cause confusion. The major reason was that there was no evidence of actual confusion. He observed: ${ }^{162}$

It should not have been very hard for Libman to find some satisfied owners of its brooms and confront them with the Vining broom and see whether they thought it was the same brand of broom. Without such evidence it would be pure speculation to conclude that anyone, let alone a significant fraction of the broom-buying public, could have been misled into believing that the Vining broom and the Libman broom were one and the same brand.

Judge Coffey vigorously dissented. ${ }^{163}$ He held the district court had applied the correct test. He explained the lack of confusion evidence as due to the low cost of the brooms. ${ }^{164}$ Consumers would be unlikely to complain when dissatisfied. Thus no confusion would be brought to light. He further accused the majority of giving too much analytical weight to the actual (or lack of) confusion factor. ${ }^{165}$

Such disagreements are not confined to Bali and Libman. Of the fifty eight cases in this article and its footnotes which discuss lack of evidence of confusion there were

158 Bali, above n 139, 435-436; See also HP Bulmer, above n 37, 126.

159 Bali, above n 47.

160 Bali, above n 47, 498.

161 Libman, above n 154.

162 Libman, above n 154, 1754.

163 Libman, above n 154, 1754-1758.

164 Libman, above n 154, 1755.

165 Libman, above n 154, 1758. 
disagreements as to result in thirty two of them. This shows that rather than being a determinative factor, lack of evidence of confusion is only a factor in determining likely confusion. It may be significant. It may not be. Perhaps only in situations such as Hannaford \& Burton can it be truly decisive. And one should remember in Hannaford \& Burton the Privy Council overruled the New Zealand Court of Appeal ${ }^{166}$ which overruled the Supreme Court. ${ }^{167}$

\section{CONCLUSION}

The presence or absence of evidence of actual confusion is important in trade mark litigation. However, it is only a factor. Its importance varies from case to case.

As for presence of evidence of confusion its importance depends on whom was confused, the number of incidents of confusion, and the type and cost of the product involved.

As for lack of evidence of confusion this can be meaningless if there has been little or no scope for confusion to arise. Many other valid reasons can exist to explain the lack of evidence. If a party cannot readily explain the lack of confusion then a tribunal can treat the lack of evidence as probative. Whether it is significant depends on the circumstances and upon whether a party can plausibly explain the lack of such evidence.

Tribunals should closely examine the circumstances of each case before deciding such evidence is probative.

Even if the facts indicate it is relevant it is not the only factor a tribunal must consider. Even then such evidence can always bend to the eye and ear of the individual tribunal.

166 Polaroid Corporation v Hannaford \& Burton Ltd [1975] 1 NZLR 566 (CA).

167 Polaroid Corporation v Hannaford \& Burton Ltd [1974] 1 NZLR 368 (SC). 